\title{
Zieleń jako element kstałtowania miejskich przestrzeni publicznych dedykowanych kulturze - wybrane przykłady
}

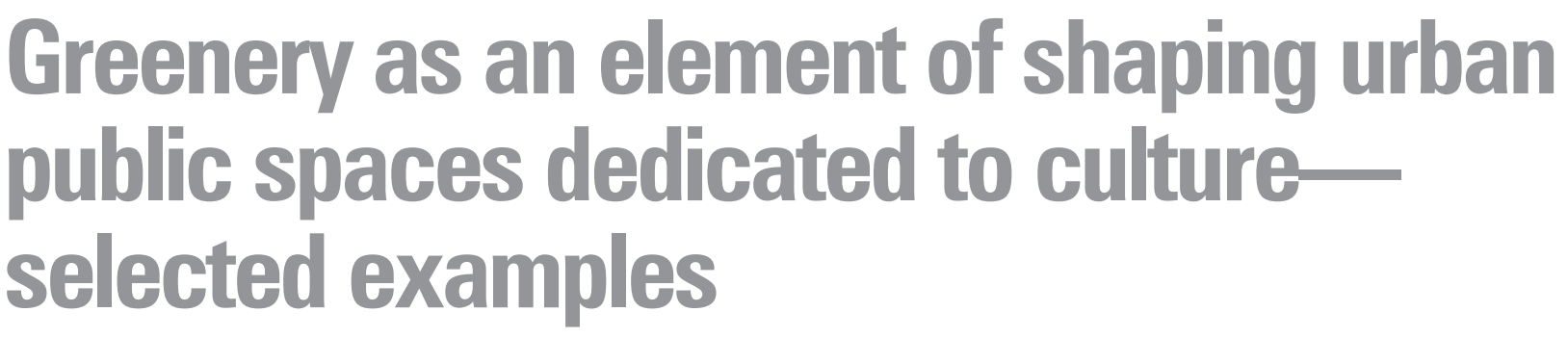

\begin{abstract}
Streszczenie
Obiekty i zespoły architektoniczno-urbanistyczne związane z funkcjami kultury stanowią obecnie w miastach europejskich znaczące dla ich statusu i wizerunku elementy struktury przestrzennej. Współtworzą istotne sekwencje wnętrz urbanistyczno-krajobrazowych, zarówno w obrębie historycznych układów przestrzennych, jak i nowo projektowanych, w tym najczęściej poddawanych procesom rewitalizacyjnym, fragmentów tkanki miejskiej. Wielu z tych przestrzeni towarzyszą kompozycje zielone, najczęściej w postaci niewielkich klombów lub szpalerów drzew, podkreślających monumentalizm założeń urbanistycznych i architektonicznych, które mają symbolizować rangę i pozycję poszczególnych instytucji kultury. Poza historycznymi założeniami rezydencjalno-parkowymi, adaptowanymi obecnie na funkcje związane z kultura, niezwykle rzadko zdarza się, aby skomponowana zieleń dominowała w tego typu założeniach, nie będąc przede wszystkim tłem dla architektury, ale równoprawnym, jeśli nawet nie- dominującym, elementem kształtującym miejską przestrzeń publiczną. Publikacja przywołuje kilka przykładów współczesnych realizacji takich przestrzeni w metropoliach europejskich.
\end{abstract}

\begin{abstract}
Architectural and urban structures and complexes associated with cultural functions in European cities currently constitute elements of their spatial structure that are significant to their status and image. They co-create essential sequences of urban and landscape interiors, both within historical spatial layouts, as well as newly-designed ones, most commonly including those fragments of urban tissue that are subjected to urban regeneration processes. Many of these spaces are accompanied by green compositions, most commonly in the form of small flower-beds or rows of trees that highlight the monumentalism of urban and architectural complexes and which are meant to symbolise the rank and position of individual cultural institutions. Apart from historical park and residence complexes that are currently being adapted to functions associated with culture, it is very rare for arranged greenery to dominate in these types of layouts, instead of primarily serving as a background for architecture-an equally significant if not a non-dominant element that shapes urban public space. The publication refers to a number of examples of contemporary built projects of such spaces in European metropolises.
\end{abstract}

Słowa kluczowe: park, przestrzeń publiczna, urbanistyka krajobrazu, przestrzenie kultury, miasto europejskie Keywords: park, public space, landscape urbanism, spaces of culture, European city

\section{Wprowadzenie}

Zieleń towarzyszyła człowiekowi, a zarazem i tworzonej przez niego architekturze od zarania dziejów, będąc źródłem budulca, pożywienia, schronieniem przed zmiennymi warunkami pogodowymi. W różnych okresach historycznych rola zieleni w miastach zmieniała się z czysto utylitarnej, poprzez bardziej dekoracyjną, aż po hybrydową, która powinna łączyć te oba aspekty. Wreszciewe współczesnych metropoliach - stała się koniecznym i niezbędnym elementem struktury przestrzennej miasta ${ }^{1}$, który wraz z innymi czynnikami kształtuje zdrowe

\section{Introduction}

Greenery has accompanied man and the architecture created by him since the dawn of history, serving as a source of building material, food and shelter from changing weather conditions. Throughout various historical periods the role of greenery changed from a purely utilitarian function, through a more decorative role, to a hybrid one, which should combine these two aspects. Finally-in contemporary metropolises-it has become a necessary and indispensible element of the spatial structure of the city ${ }^{1}$, which, along with other factors, shapes a healthy living en-

\footnotetext{
* Mateusz Gyurkovich, Institute of Urban Design, Faculty of Architecture, Cracow University of Technology, Polandl) ORCID ID: https://orcid.org/0000-0002-6685-5234, mateusz.gyurkovich@pk.edu.pl

** Adolfo Sotoca, Department of Civil, Environmental and Nature Resources Engineering, Luleå University of Technology, Sweden, adolfo.sotoca@Itu.se
} 
środowiska życia. A przede wszystkim, dzięki ruchowi znaczącą część miejskich obszarów mieszkaniowych ${ }^{3}$ Nie wszystkie dzielnice i rodzaje zabudowy sa jednak kojarzone z zagospodarowaną zielenią miejską. Niekiedy, zwłaszcza w historycznych centrach wielu europejskich metropolii, wystepuje ona sporadycznie, a sekwencje przestrzeni publicznych stanowia przede wszystkim wybrukowane place i ulice. Tak sie dzieje zarówno we - wcale nie pozbawionych przez to uroku - miastach - whaskich i hiszpáskich ${ }^{4}$, prez to uroku - miastach

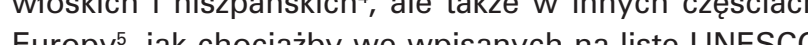
zabytkowych układach urbanistycznych Krakowa, czy Torunia. Wtórne wprowadzanie zieleni w pozbawioną jej Torunia. Wtorne wprowadzanie zieleni w pozbawioną jej
dotychczas historyczną tkankę miejską, przynosi niekiedotychczas historyczną tkanke

dy spektakularne rezultaty ${ }^{6}$. Obiekty i zespoły architektoniczno-urbanistyczne zwią-
zane z funkcjami kultury wysokiej' stanowią obecnie zane z funkcjami kultury wysokiej ${ }^{7}$ stanowią obecnie
$w$ miastach europejskich znaczące dla ich statusu i wiw miastach europejskich znaczące dla ich statusu isi-
zerunku elementy struktury przestrzennejs. Poza historycznymi założeniami rezydencjalno-parkowymi, adaptowanymio rzadko zdarza się, aby towarzyszyły im duże kompleksy zieleni. Najczęściej zieleń $w$ towarzyszących im przestrzeniach publicznych ogranicza się do niewielkich klombów lub szpalerow drzew, podkreślających monumentalizm założen urbanistycznych $i$ architektonicznych które mają symbolizować rangę i pozycję poszczególnych instytucji kultury. Na fali mody, ale także, zdaniem autorów, konieczności zrównoważenia ekologicznego rozwoju miast, pojawia się coraz więcej przykładów wspófczesnych realizacji, w których skomponowane zatożenia zielone, nie są jedynie tłem dla architektury, ale równoprawnym, jeśli nawet nie - dominującym, elementem kształtującym miejską przestrzeń publiczną.

\section{Skwer Willy'ego Brandta w Warszawie}

Jednym z najważniejszych i zarazem najpiękniejszych obiektów kultury, jakie oddano do użytku w Polsce w ostatnich latach jest Muzeum Historii Żydów Polskich (POLIN) w Warszawie ${ }^{9}$. Usytuowano je na Muranowie, w północno-wschodniej cześci zrównanego z ziemia pod koniec II wojny światowej, a wcześniej założonego przez hitlerowców warszawskiego getta. Podczas powojennej odbudowy dzielnicy, kwartał pomiędzy obecnym ulicami : Karmelicką, M. Edelmana, L. Zamenhofa i M. Anielewicza pozostawiono jako zielony skwer. Otoczony jest osiedlową zabudową mieszkaniową, realizowana od lat 50. do lat 80. XX wieku. Na jego wschodniej krawędzi znajduje się monumentalny, przytłaczający swoją wymową pomnik upamiętniający bohaterów krwawo stłumionego przez gestapo powstania, które wybuchło w warszawskim getcie w 1943 roku $^{10}$. Ustawiony na kwadratowym, wybrukowanym czarnym bazaltem pla$\mathrm{cu}$, przez dziesięciolecia stanowit o wymowie i charakterze znajdującej się na jego tyłach przestrzeni zielonej. Decyzja o lokalizacji muzeum POLIN w centrum skwe- vironment. However, first and foremost, thanks to the modern movement and its aftermath', it should constute a significant part of urban residential are$\mathrm{as}^{3}$. Not all districts and types of development are however, associated with arranged urban greenery. Sometimes, particularly in the historical centres of present and sequences of public spaces are primar ily composed of paved streets and squares. This is happening both in Italian and Spanish ${ }^{4}$ cities-which are not without their charm-as well as in other parts of Europe ${ }^{5}$, such as, for instance, the historical urban layouts of Krakow or Torun that are on the UNESO World Heritage Site list. The later introduction of greenery into historical urban tissue that had no included it sometimes results in spectacular effects ${ }^{6}$. Architectural and urban structures and complexes associated with functions of high culture presently $^{-1}$ constitute elements of spatial structures that are sig-
nificant to the status and image of European cities in which they are located $d^{8}$. Apart from historical residential and park complexes that are currently adapted to purposes associated with culture, it is very uncommo for large complexes of greenery to accompany them Most often, greenery in their accompanying public spaces is limited to small flower-beds or rows of trees that highlight the monumentalism of urban and architectural layouts which are meant to symbolise the rank and position of the individual cultural institutions. the authors the necessity to make the develording to cities ecologically sustainable, an increasing amoun of examples of contemporary built projects are appearing in which arranged green complexes are not only a background for architecture, but an equal, if not dominant, element that shapes urban public space.

Willy Brandt Garden Square in Warsaw One of the most important and at the same time mos beautiful cultural buildings that have become open for use in Poland in recent years is the Museum of the History of Polish Jews (POLIN) in Warsaw'. It is locat saw ghetto that had been established by the Nazis and later destroyed near the end of the Second World War. During the post-war reconstruction of the district the urban block between the current Karmelicka, M. Edelmana, L. Zamenhofa and M. Anielewicza streets was left undeveloped as a garden square. It is surrounded by housing-estate-like residential buildings that were built between the 1950's and the 1980's. On its eastern edge there is a monumental memorial, overwhelming in its expression, in remembrance of the heroes of the was bloodily suppressed by the Gestapo in 1943 and was bloodily suppressed by the Gestapo ${ }^{10}$. Placed on set the tone of the expression and character of the green space behind it for decades.

The decision concerning the placement of the POLIN Museum in the centre of the garden square has completely altered its role in the system of the capital's public spaces, as well as its reception by residents and increasing numbers of tourists" ${ }^{11}$. The museum building was built upon a square-shaped plan, identica ru, całkowicie zmienita jego rolę $\mathrm{w}$ systemie publicznych raz liczniejszych turystów ${ }^{11}$. Obiekt muzeum wzniesiono n planie kwadratu, identycznego z placem pod pomnikiem na którego zachodniej krawędzi go wybudowano. Prze kształcony częściowo skwer został wciagnięty w kompozycje całego założenia. Stanowi o wyjatkowości tej prze strzeni kultury, na równi z ikoniczną architekturą muzeum Otacza obiekt z wszystkich stron oferuiac przestrzenie zielone o zróżnicowaj formie, funkcij i kompozycij. Od trony pomika i zarazem gó́w funo wej́cia do muz. Od ro geometryczy, liniowy ukad rabat i nacadzeń róż wysokosi'12, podkreślony szpalerami drzew, najuzjacy w spośb oczyisty do elewail budynu i decydujacego

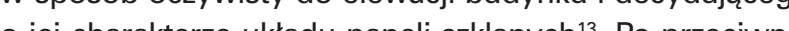
jejon cha stronie budy ku kompozycja skwer staje sie dużo swobodniejsza, sprzyjająca rekreacj. Pofalowana, zielona ląka, otoczona drzewami, na którą od strony zachodniej otwiera się szklana sciana kikukondygnacyjnego foyer, wydaje sie być konynuają falstych, zaklecych w kamien form whetrza, nawiązujących do rozstępujących się fal Morza Cze wonego ${ }^{14}$. W sezonie letnim jest ona popularnym wśród okolicznych mieszkanców i przybywających tu licznie turystów miejscem wypoczynku, czy nawet plażowania.

Przestrzen ta w sposób harmonijny przenika się z międzyblokową zielenią okolicznych osiedli mieszkaniowych, pozostając zarazem wyróżnioną poprzez znajdujące się w jej obrębie funkcje kultury. Zielonkaw kolorystyka kamienia i szkła, użytych na fasadach jest jakoby kontynuacją otaczającej muzeum POLIN, przetworzonej ręką człowieka przyrody. Przyjęty przez projektantów cel stworzenia żyjącej przestrzeni miejskiej został osiągnięty przede wszystkim dzięki znaczącej in tegracji obiektu z dominujaca nad nim powierzchniowo, a niekiedy i wysokościowo, otaczająca zielenią. Otwarcie monumentalnym przeszkleniem na skwer ma symbolzować, ze (. Jhistoria nie zostafa zamknieta, a Muzeum POLIN jest muzeum życia (...) ${ }^{16}$.

\section{Ogrody im. Miquel Marti i Pol w Barcelonie}

Transformacja poprzemystowej dzielnicy El Poblenou, zajmujacej blisko $1 / 3$ powierzchni Eixample ${ }^{17}$, pod nazwą22@ była jednym z najwiekszych projektów urbanistycznych prowadzonych w Barcelonie od początku XX wieku. Jak się okazało, przyjęta przeszło sto pięćdziesiąt la temu matryca dziewiętnastowiecznego miasta przyszłośc doskonale sprawdza się przy kreowaniu współczesnyc struktur przestrzennych o odmiennej od pierwotnie zakładanych funkcji i typologii. Niezwykle ważne w tym procesie było zachowanie rellktow dziedzictwa poprzemysłowego, przede wszystkim fabrycznych kominów, które zawsze stanowily najważniejsze dominanty $w$ tej części miasta, a także najbardziej wartościowych obiektów kubaturowych ${ }^{18}$. Do dzisiaj, po 18 latach od rozpoczęcia działa rewitalizacyjnych, wszystkie zalozenia projektu 22@Barcelona nie zostały zrealizowane, ale będąc wytycznymi dla opracowywanych później planów miejscowych, wciąż to the square underneath the monument, on whose western edge it was built. The partially tr garden square became incorporated into the composition of the entire layout. It causes this cultural space to be unique, equally to the iconic architecture of the museum. It surrounds the building from all sides, of fering green spaces with varying forms, function and the same time, the main entrance to the museum, it is geometric linear layout of flower-beds and plantings of varying height ${ }^{2}$, highlighted by rows of trees, which refer in an obvious manner to the facade of the building and the layout of glass panels that determine its character $^{13}$. On the opposite side of the building the composition of the garden square becomes much more freeform and conducive to recreation. The undulating green meadow, surrounded by trees, onto which the glass wall of the several-storeys-high foyer opens up appears to be a continuation of the undulating form of waters of the Red Sea $a^{14}$. During the summer season it is a popular $\mathrm{pl}$. and tourists who come here in large numbers.

This space harmoniously blends in with the greenery between the apartment blocks of the neighbouring housing estates, while simultaneously still being highlighted by the cultural functions located inside it. The greenish colour of the stone and glass used on the facades is a sort of continuation of the nature that surrounds the POLIN Museum-nature altered by man's hand. The goal of creating a green urban space 15 adopted by the designers has been achieved primarily through the significant integration of the structure with the surrounding greenery that domheight as well. The opening towards the garden square through a monumental glazing is meant to symbolise "...) that history has not yet ended, and symbolise "(..) that history has not yet ended, and
that POLIN Museum is indeed a museum of life (...)

The Miquel Marti i Pol Gardens in Barcelona The transformation of the post-industrial El Poblenou district, which occupies close to 1/3 of the area of Eixample ${ }^{17}$, under the name 22@ was one of the greatest urban planning projects conducted in Barcelona since the start of the twenty-first century. As it turned out, the was adopted over a hundred and fifty years ago works perfectly in the creation of contemporary spatial structures with functions and typologies that are different to the ones that had originally been planned. The preservation of the remains of post-industrial heritage was extraordinarily important in this process, particularly concerning factory smokestacks which have always constituted the most important landmarks of this part of the city, as well as of the most valuable buildings ${ }^{18}$. To this day, after 18 years since the start of urban regeneration efforts, not all of the objectives of the 22@ Barcelona project have been completed, however, as they layer they still affect the changes and transformapiod in this part of the city $y^{9}$. The continuation of the continuity of the development of urban structures that has lasted over two thousand years is still ongoing. 
wpływają na zmiany i przekształcenia tej części miasta19. lat, ciągłości rozwoju struktur urbanistycznych wciąż trwa.

Jako jeden z pierwszych fragmentów rewitalizowane tkanki El Poblenou, zrealizowano obszar kilku kwartatów zabudowy, tzw. Eix Llacuna, w ramach którego powstały ikoniczne dla transformacji obszaru obiekty i zespoły ${ }^{20}$. Jednym z nich stało sie muzeum Can Framis ${ }^{21}$ urzadzone w obiektach zaadaptowanej na ten cel i przebudowane; dawnej przedzani welny. Jest wanej, daw instórej kor katalons go kwall Eura

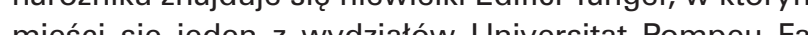
miesci sie jeden z wydzialow Universitat Pompeu Fa$\mathrm{bra}^{2}$. Dominantą przestrzenna zespolu pozostaje dawny komin fabryczny, ukryty na niedużym, ogólnodostępbetonowa architektura nowej części obiektu, przeplata się z reliktami dwóch pofabrycznych budynków, które zostały odnowione również $w$ bardzo oszczędny sposób. Część istniejacych okien zamurowano pozostawiając zarys dawnych otworów. Wszystkie historyczne elewacje zostaly pokryte wapienną zaprawą, nawiązująca do struktury surowych betonowych ścian nowych fragmentów, jednak różni je od nich widoczna faktura cegieł. Wykreowany od strony południowej, obszerny dziedziniec wejściowy, wymykany bramą $\mathrm{w}$ formie łańcuszkowej, transparentnej siatki, bywa często wykorzystywany jako dodatkowa przestrzeń ekspozycyjna.

Wszystkie przestrzenie publiczne: place i dziedzińce oraz zaadaptowane do funkcji kultury budynki pofabryczne ukryte sa jednak we wnettrzu kwartału I - chociaż widoczne z otaczajacych ulic, a cześciowo nawet do nich styczne-pozostaja odciese on jednym z najciekwszych elementów tej przestrzen publicznej. Nieco tajemnicze, otaczajace budyni i wy-

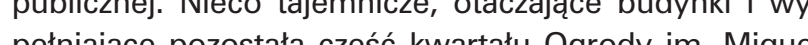
Merti i Pol ${ }^{24}$ sa zielona wyspa 25 w skali dzienicy. A zar

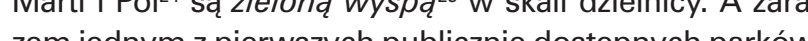

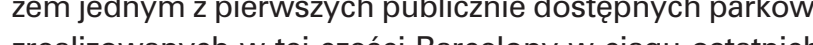
zrealzownz w w te czesci Barcelony w ciegu ostatnich dekad. Slaza nie tyko odwiedzajacym muzeum, ale takze mieszkan nom okolicznych kwantón i pracownikom sąsiednich biur. Swobodna, meandrująca kompozycja niewielkiego, ciasnego gaju, $w$ ktorym przewazaja rosliny kwhące, bluszcze oraz rodzime gatuni drzew, doskonale uzupełnia i podkreśla surowość brył muzeum. Zmienna topografia sprawia, Że ogrody wydają się być wyizolowane od otaczających je z czterech stron ulic. Ogromna zaletą tej kompozycji zielonej jest stworzenie przestrzen sacrum, separującej muzeum- świątynię sztuki od zgiełku dzielnicy, kora zazzen jest także miejscem spoka i żywą przestrzenią publiczną ${ }^{26}$. Srodziemnomorski klima sprawia, że przestrzeń ta, najpiękniejsza na wiosnę, od kwietnia do czerwca, kiedy wszystkie rośliny kwitną, pozostaje atrakcyjna przez cały rok.
As one of the first fragments of the revitalised tissue velopment, so-called Eix Llacuna, has been compleed, featuring buildings and complexes iconic to the transformation of the area ${ }^{20}$. The Can Framis ${ }^{21}$ muse um has become one such structure, established in ed and redeveloped for this purpose. It is one of the many institutions belonging to the private Vila Cas Foundation ${ }^{22}$, whose main goal is the promotion of contemporary Catalan art. The museum and the oundation occupy the centre of a typical Eixample urban block, furthermore, in the north-eastern corne there is the small Edifici Tanger, which houses one of the faculties of Universitat Fabra ${ }^{23}$. A former factory smokestack, hidden on a small, freely accessible northern courtyard, remains the spatial landmark of the complex. The concrete architecture of the new part of the structure, minimalist in its expression, in ings which were also renovated in a very austere manner. Some of the renovated in a very austere up, leaving an outline of their former openings. All of the historical facades were covered with lime plas$\mathrm{er}$, referring to the structure of the austere concrete walls of the new fragments. However, they differ from them due to the visible brick pattern. The expansive entrance courtyard formed to the south, closed by a gate in the form of a chain-link transparent mesh, is Alt

All the public spaces: squares and courtyards and the former factory buildings adapted to culture-re And-although visible from the surrounding streck and partially adjacent to themby a delicate cocoon of greenery. It is one of the most interesting elements of this public space. The somewhat mysterious Miquel Marti i Pol Gardens ${ }^{2}$ that surround the buildings and fill in the remaining part of the urban block are a green island on the scale of the districte25. It has also become one of the first publicly accessible parks built in this part of Barcelona in recent decades. They serve not only the museum's visitors, but also the residents of the nearby urban blocks and the employees of neighbouring office buildings. The loose, meandering blooming of the small, cramped grove in which dominant perfectly complements and highlights the austerity of the museum's massings. The changing topography causes the gardens to appear isolated from the streets that surround them on four sides. One immense advantage of this green composition is that it forms a place of the sacred which separates the museum-a temple of the arts-from the noise of the district, which is also a meeting place and a living public space ${ }^{26}$. The Mediterranean climate cause this space, which is the most beautiful during spring, between April and June, when all the plants are in

\section{The Katyn Museum at the Warsaw Citade}

Muzeum Katyńskie w Cytadeli Warszawskiej nego do uzytku w 2015 Muzeum Katyńskiego w Cytade Warszawskiej. Zamordowanie tysięcy polskich oficerów policjantów, urzędników państwowych i duchownyc przez Sowietów na początku II wojny światowej, było jedną z największych zbrodni ludobójstwa tamtych czasów. Ich masowe groby zostały odkryte w 1941 w Lesi Katyńskim w okolicach Smoleńska ${ }^{27}$. Pamieć o zbrodni Katyńskim w nizmu w Pola z be Muzeum Katyńskego, upamietniajcego te zbrodie best niezwy Ke wymowny. Ogrom zbu nowy zosta przez rosyskich zaborców nod bre-

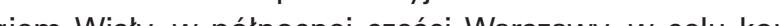

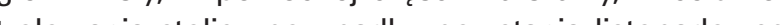

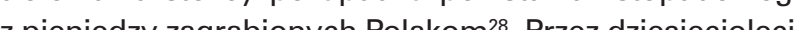
z pienięzy zagry po upa była miejscem stacjonowania carskiego garnizonu, a za razem takí miejscem i symbolem rosyjskich represji na ziemiach polskich. Pomimo zniszczen części struktury podczas II wojny światowej, do niedawna w większośc a obecnie nadal w częsci, Cytadela użytkowana jest przez wojsko. Tym bardziej otwarcie jej fragmentu, jako obiekt publicznego, ma znaczenie symboliczne ${ }^{29}$

Muzeum urządzono $w$ niewielkim fragmencie twierdzy edynej w calości ocalatej kaponierze . Adaptowane nowe cele obiekty ${ }^{31}$ poddano przy okazji gruntownym zabiegom konserwatorskim, szczegołowo omówionym w publikacjach naukowych ${ }^{32}$. Narracja obiektu jest wielowątkowa, odwołujaca się zarowno do udokumentowania tego historycznego wydarzenia, jak i personalnie, do upamiętnienia pojedynczych ofiar zbrodni sowieckiej. Równocześnie, w sensie przestrzennym, odbywa się na wielu płaszczyznach- od całego założenia urbanistyczno-krajobrazowego ${ }^{33}$ poprzez detal urbanistyczny, mata architektur zieleń, az po wnetrza zaadaptowanych nowe cele obiektów kubaturowych oraz poszczegó fragmenty ekspozycij. W sensie urbanistyczno-krajorazowym Muzeum Katýskie zostato zaprojektowane z niezyla staram Kán o klimat i cha zakter poszczeǵ́n polaczonych ze soba sekwencyinie wnetzoraz z wielka do coscia o buduace napiecie iwspom ajaze zwiek la porjecte kadr. Wspoltworza one powazny nastroj, od-

Po przejsciu przez odrestaurowaną Bramę Nowomie ską, w której zabudowaniach urządzono kasy, sklepik muzealny i niewielkie zaplecze techniczno-sanitarne, zwiedzający kierowani są w prawo, wzdłuż porośniętego zielenią muru, mogąc zarazem obserwować po drugie stronie wąskiej jezdni wciąż funkcjonujące, ogrodzon siatką tereny i obiekty wojskowe. Następnie, przez waskie przejscie dostają się na duży wewnętrzny dziedzi niec, ktory został zamieniony w reprezentacyjna, a zarazem bardzo zieloną strefę wejsciową do własciwego obiektu muzeum. To tzw. plac apelowy. Jego najważniejszym elementem jest instalacja „WARTA" złożona ze stu przystrzyzonych grabów, posadzonych na planie kwa- for use in 2015, plays a completely different role. The killing of thousands of Polish army officers, policemen, state officials and men of the cloth by the Soviets at the start of the Second World War was one of the greatest acts of genocide of that time. Their mass graves were discovered in 1941 in the Katyn Forest, was bned and suppressed throughout the entire period of communist rule in Poland. The selection of the Warsaw Citadel as the seat of the Katyn Museum commemorating this massacre is extraordinarily telling. The enormous pentagonal fortress was built by the Russian partitioning authorities on the shore of the River Vistula, in the northern part of Warsaw, in order to control the capital after the failed November Uprising and had been funded using money take from Poles ${ }^{28}$. It had been the place of the stationing of a Russian garrison force for decades, as well as the site and symbol of Russian repressions on Polish lands. of which was damaged until recently, while currently it wh only wartially daged until recently, while currently War the Citadel is being used by the military. This further stresses the symbolic significance of the opening of its fragment as a public building ${ }^{29}$.

The museum was arranged in a small part of the fortress-the only undamaged caponier $r^{30}$. The structures $^{31}$ that were adapted to new purposes were subjected to thorough conservation work, discussed in detail in scientific publications $\mathbf{s}^{32}$. The structure's narrative is multi-threaded, referring both to the documenting of this historical event, as well as to the personal remembrance of the individual victims of the time in a planes-from the entire urban and landscape layout $^{33}$, through urban detail, street furniture, greenery, all the way to the interiors of buildings adapted to new forms of use and the individual exhibition frag ments. In terms of urban planning and the landscape, the Katyn Museum was designed with extraordinary care for the atmosphere and character of the individual sequentially connected interiors and with great attention to frames that build tension and support the arrative. They co-create the solemn atmosphere appropriate for the presentation of the exhibits.

mhe museum store and the small technical and sanitary facilities, the visitors are directed to the right along a wall covered in greenery and can observe the still-functiona buildings and areas of the military located on the other side of a narrow carriageway. Afterwards, through a narrow passage, the visitors reach a large internal courtyard which has been converted into a representative and entrance zone to the museum building proper featuring large amounts of greenery. It is the so-called drill square. Its most important element is the "WARTA" ("The Watch" in English-transl. note) installation planted on a square plan based on an orthogonal, gepricised grid ${ }^{34}$. The pavement that leads from the 
dratu, w oparciu o ortogonalną zgeometryzowaną siat$\mathrm{ke}^{34}$. Chodnik prowadzacy od wejscia na plac do drzw zamienionej na muzeum czessci budynków fortecznych, przechodzi zakosami przez środek tego zagajnika, zagtebiajac się nieco pod ziemie. Instalacji od strony placu towarzyszy wysoki, prosty Krzyż Katyński.

Bujna zieleń, która przez dekady porosła dziewiętnastowieczna strukture pofortyfikacyina została wciagnięta w kompozycje i narracje muzeum. Wzbogacona zosta nazyci i nanków charakterystycznych dla obszarów Rosi, Biatorusi i Ukrainy, czyli tych, gdzie odkyto món Rosil Baby pomi pacych przez waski otwór wic murze dwakondygnacyjna, i pochómk of

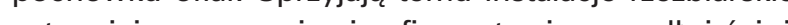
puste miejsca na popiersia ofiar, ustawione wzd hż ścieżki, wijącej się possrod drzew wewnątrz okolonej wysokim wałami i ceglanym murem fosy fortecznej. Na jej zakoń czeniu, warkadach dawnej baterl bunkrowej, urządzono Strefę Pamięci. Poszczególne, połączone amfiladowo pomieszczenia zawierają tablice z nazwiskami ofiar, uszeegowane według wyznań (katolicy, protestanci, grekokatolicy, prawosławni, żydzi, mahometanie, itd.), które otwieraja się szerokimi arkadami ze szklanymi drzwiam w kierunku porastającego dawną fosę lasu. Wąska szpara w wale twierdzy, miesci ujęte $w$ dwie ściany schody, prowadzące z dolnego poziomu baterii barkowej, sprzed centralnej arkady z powrotem, wprost na plac apelowy. Usytuowane dokładnie na osi znajdującego się tam wspomnianego Krzyża Katyńskiego, wykończone zostały zabarwionym na czerwono betonem, co nawiazuje zarówno do ceglanych murów zabytkowych części fortyfikacii, jak i symbolicznie- do krwi ofiar. Zieleń, zarówno ta istniejaca, jak i nowoprojektowana, stała sie doskonatym tworzywem, uzupełniajacym nie tylko kompozycie archi-

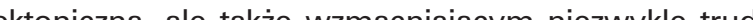
przekaz ideowy tego muzeum.

\section{Podsumowani}

Zieleń nie jest tworzywem, jakie kojarzy się ze współ(a) ich skali. Zazwyczaj, jak już to zaznaczono na wstępie, stanowi niewielkie kompozycyjne uzupełnienia lub tro dla architektury, czy monumentalnych w charakterze przestrzeni placów, towarzyszących poszczególnym biektom. Obecnie coraz częściej traktowana jest jako ksponat, lub swoista instalacja artystyczna ${ }^{36}$. Przedstawione $\mathrm{w}$ artykule przykłady ukazują, że może być takze inaczej. Zielone przestrzenie publiczne podkresiaja wyjątkowośc przestrzeni kultury w monotonnej ${ }^{37}$, lub własnie zbyt dynamicznejej tkance miejskiej. Stanowia oprawę dla niecodziennej architektury budynków muzealnych, a zarazem potrzebną do kontemplacji strefe wyciszenia. W przypadku Muzeum Katynskiego w Warszawie współtworzy narrację ekspozycji muzeum, przechodząc raz po raz z roli tła, w rolę głównej ekspozycji. the middle of this grove, going slightly below ground The lush greenery that has covered the nineteenth-century structures of the former fortress for decades has been included into the composition an planting of species distinct of the reas of Russia Be larus and Ukraine- where the sites of the discovery of the mass graves of the victims of the massacre had been discovered. It constitutes a metaphor of those forests and seems to transport the visitors who leave the two-storey underground part of the exhibition through a narrow opening in a wall, to the distant memorial places of the burial and commemoration of the victims. This is aided by sculptural installations, empty spaces meant for the busts of victims, placed along the path that winds between the trees inside the fortress moat, surrounded by tall embankments and a brick wer battery end, in the arcades of the former bunThe individul rooms, forming an enfilate plaques with the names of the victims, ordered according to their religion (Catholics, Protestants, Greek Catholics, Orthodox Christians, Jews, Muslims, etc. which open up through wide arcades with glass doors in the direction of the forest that grows in the moat. The narrow slit in the fortress' embankment houses stairs framed by two walls, leading to the lower level of the flank battery, back from the central arcade, directly onto the drill square. Placed exactly on the axis of the aforementioned Katyn Cross located there, which is a reference both to the brick walls of thete torical part of the fortifications and--symbolically the blood of the victims. The greenery, both through its the existing and newly-designed parts, became the perfect material, supplementing not only the architecperfect material, supplementing not only the architecnarily difficult ideological message of this museum.

Conclusion

Greenery is not a material that is associated with contemporary built projects of cultural spaces, regardless of their scale. Usually, as it has already been highlighted in the introduction, it constitutes smal architecture or the monumental spaces of square that accompany individual buildings. At present it is more and more often treated as an exhibition element or a sort of artistic installation ${ }^{36}$. The examples presented in the article demonstrate that it can be different. Green public spaces highlight the exceptionality of the spaces of culture in a monotonous ${ }^{37}$ or excessively dynamic ${ }^{38}$ urban tissue. They constitute a framing for the extraordinary architecture of museum buildings and at the same time a space of peace and quiet, necessary for contemplation. In the case of the Katyn Museum in Warsaw, it co-creates the bly entering the role of a background and that of the main exhibition. This unusual treatment of greenery on such a large scale appears to be a new trend in the composing of cultural spaces.
To niecodzienne potraktowanie zieleni, na tak wielką owym trendem w komponowaniu przestrzeni kultury.

PRZYPISY

Mowa. A. Zachariasz (2016)

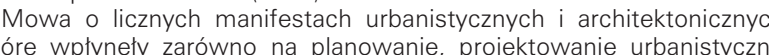
-architektoniczne, a takiz liczne dokumenty prawne i ustawodawstwo na

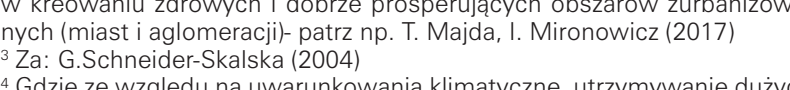
“Gdzie ze wagledsuna uwarunkowania klimatyczne, utrzymywanie duzyy obszarow zielonych $w$ obrebbie tkanki miejskiej, bywayto w przeszlości
niekiedy, pomimo nowych moziliwości technologicznych-nadal pozosta je) Kosztowne i klopotiliwe
50 znacznie wilgotniejszym Jak to sie dzieje np. W Barcelonie, gdzie wiele wnetrz XIX-wiecznyc

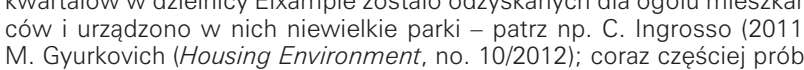
worzenia mikro parków w obrebie gestej tkanki miejskiej podejmowan Muzea, galerie stutuki, teatry, opery, sale koncertowe

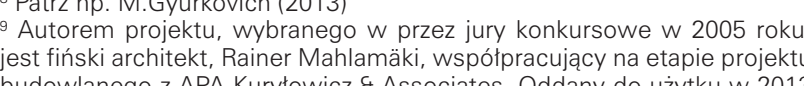

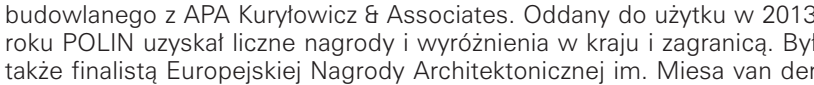
Rohe w 2015 roku-www.polin.pl/////budynek; dostep luty 2017

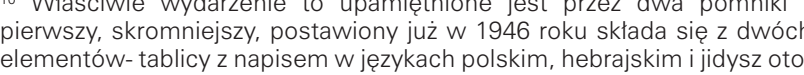

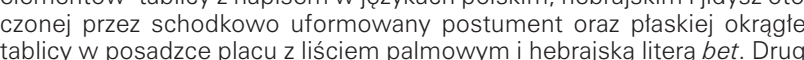
pomnik, który do niedawna dominowat nad skwerem, w każdym razie na
pewno znaczeniowo, wykonany z czarnego, skandynawskiego kamienia

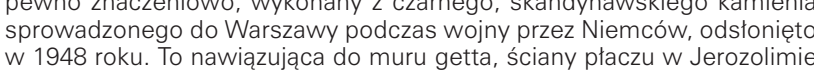
oraz pylonów Łuku Tryumfalnego w Paryżu, kompozycja rzébibiarska au
torstwa N Rappaporta i L.M. Suzina- www encyklopedia. pwn.pl: dostep

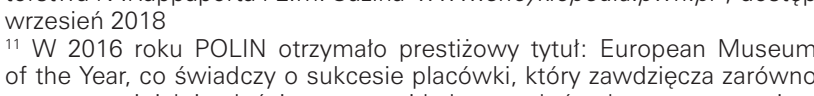

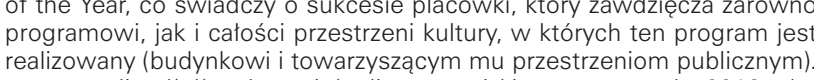
www.polin.pl/p///Wy
step wrzesieñ 2018

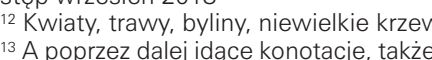

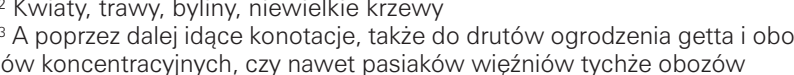
20w koncentracyinych, czy nawet pasiakow więz
14 Patrz A. Cymer (2013)
${ }^{5}$ Wypowiedź autorska- $R$. Mahlamäki- ibidem

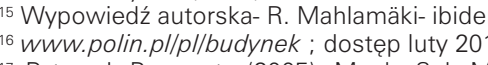

17. Patrz: J. J. Busquets (2005), M. de Sola-Morales (2011) , C. Ingrosso, op.cit
${ }_{18} \mathrm{~A}$ niekiedy tylko ich fragmentów- fasad, elementów konstrukcji lub wy posazenia, co zostato doktadnio określone w wrzyjettym planie rewitalizacij
dzielnicy i wytycznych konserwatorskich - patrz: $22 @$. 10 Anys de reno dziellnicy i wytycznych
vació urbana (2012)
19 Patrz nP

190

Jak np. obiekt Media-TC, czy kampus Universitat Pompeu Fabra w daw21 Projekt muzueum powstat $w$ barcelońskiej pracowni BAAS. Autor:
Badia z zespotem: 2007-2008- za: Miralles R., Sierra P. (2010) 2. Zaatozizana w 1986 roku przez przedsiębiorce farmaceutyczenego, Anton

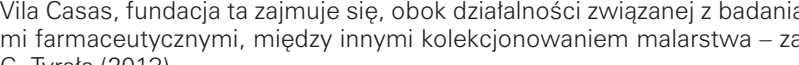
Reszta kampur

mpusu Ca I'Aranyo znajduje się w kwartale sasiaduiacym od ${ }_{24}$ Zaprojektowany wspólnie przez pracownie BAAS Arquitectura Studio

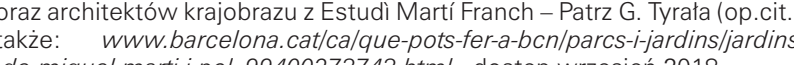

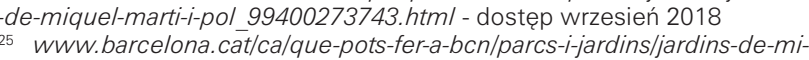
quel-marti-i-pol 99400273743. htm/ - dostepp wrzesień 2018
${ }_{26}$ Co upodabnia ja do omówionego powyziej przykladu z warszawskieg Co upoditan
ENDNOTES

See: A. Zachariasz (2016), among others.
This is a reference to the numerous urb ectural manifestoes that have influenced both planning and ard archtectural and urban design, in addition to many legal documents
and legislation all around the world. The role of green areas in the ceation of healthy and prosperous urbanised areas (cities and ag
ations) in them keeps increasing. see: T. Maidd, I. Mironow-

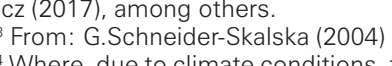
Where, due to climate conditions, the maintenance of large green heas within urban tissue was (and, sometimes, despite new tech with a much more humid climate, which would make it possible As it is, for instanme, taking place in Barcelona, where many in
teriors of the nineteenth-century district of Eixample have bee reclaimed for the general population and have had small parks
arranged inside them-see, for instance: C. Ingrosso (2011), M Gyurkovich (Housing Environment, iss. 10/20212); a attempts at creat ing micro-parks are also
(D. Wantuch-Matla, 2018

Museums, art galleries, theatres, oper
see, for instance M. Gyurkovich (2013)

The author of the design, selected by a con who

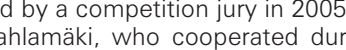
ing the technical design stage with APA Kuntowicz \& Associates.
Opened for use in 2013, POLIN received numerous awards and distinctions both domestically and internationally. It was also in the
final of the European Union Prize for Contemporary Architecture,
Mies van der Rohe Award in 2015- www.polin. pl//pl/budynek; reMies van der Rohe Award
trieved in February 2017

To be exact, the event is commemorated by two memorials: the
irst, more modest one, placed already in 1946, is composed Yiddish embedded in the floor surface of the square with a pand leaq and
the Herew letter bet. The second monument, which dominate he garden square until recently-in semantic terms, at least-Was
built out of black Scandinavian stone brought to Warsaw by the
Germans during the war and unveiled in 1948. It is a sculptural composition by N. Rappaport and L.M. Suzin that references the
wall of the ghetto, the wailing wall in Jerusalem and the pylons of the Arc de Triomphe in Paris, www.encyklopedia.pwn.pl; ;

"In 2016 PoLIN received the prestigious title: European Muse-
um of the Year, which is a sign of the museum's success, which it owes to both its programme and the entirety yof the cultural space
in which said programme is featured (the building and the accompanying public spaces). - www.polin. pl/p////wydarzenie/pol/
ropejskim-muzeum-roku-2016 - retrieved in September 2018 And through further connotations, also to the wires of the ghet-
to's walls and those of the concentration camps or even the striped

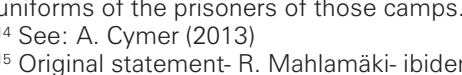

Original statement- R. Mahlamäki- ibidem
www.polin.pl/p//budynek; retrieved in Febriary 2017
See: J. Busquets (2005). M. de Sola-Morales (2011).

op.cit

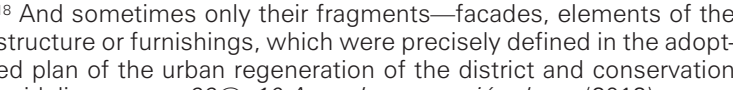

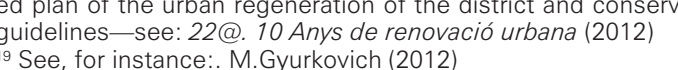
20
20 Such as the Media- II I building, or the campus of Universitar Pompeu Fabra in the former Ca l'Aranyo factory
21 The design of the museum was developed by the Barcelo-
na-based design studio BAAS. Author: J. Badia and associates. $2007-2008$ - from: Miralles R., Sierra P. (2010)
22 Founded in 1986 by a pharmaceutical entrepreneur, Antonio Vile Casas, the in foundation, apart tram its operations assouciated with pharmaceutical research, also collects paintings - from: G. Tyrata (2013)
${ }_{23}$ The rest of the Ca l'Aranyo campus is located in the urban block
directly to the north of the area in question 24 Jointly designed by BAAS Arquitectura Studio and landscape ar
chitects of Estudi Martri Franch - See: G. Tyratat lop citit), see also

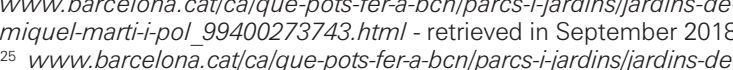

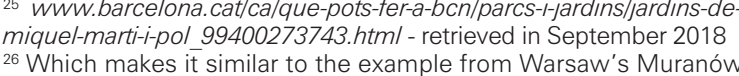
district discussed above.
27
if And in other places across the Soviet Union afterwards. Tens 
27 A nasteppnie w innych miejscach Zwiazku Radzieckiego. Zbrodni po-
swwieconyych jest dziesiątki, jezeli nie setki publikacii monograficznych. w krajui i poza granicami. Wystarczajace na potrzeby tej pracy sa jednak suche fakty encyklopedyczne-www.encyklopedia.pwn.pl- dostęp ma 281 zainaugurowana jako Cytadela Aleksandrowska w 1834 roku- ibidem
29 Od 1963 roku w Cytadeli funkcjonowato juz niewielkie muzeum po swiecone represijonwanym przez carat cltonkom ruchu robotniczego
przeksztatcone nastepnie w Muzeum Wojska Polskiego, którego omawiana placówka jest oddziałem - www.muzeumkatynskie.pl - dostep . Podstawowym zadaniem projektowym byłta adaptacia na cele muzeoraz jej otoczenia obejmujacego tzw. "droge strazi", wath, fragment
muru Carnota, Brame Nowomiejka oraz budowle baterii barkowej nr kiewicz (2017) 11 Autorami projektu Muzeum Katyńskiego w Warszawie sa BBGK A. szerokim gronem specialistów. I I Kalina i K. Lango z zacspiacy z bardzo cja uzyskata Nagrode Architektoniczna Miasta Stofecznego Warszawy dla najlepszego budynku uìyteczności publicznej w 2015 roku; byla
też nominowana do Europejskiej Nagrody im. L. Miesa van der Rohe W 2017 roku
w. JJ. Bialkiewicz, op.cit

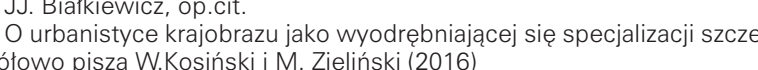
34 Przywodzi ona na myśl instalacię ztoziona z posadzonych w prosto-
padtosciennych, betonowych donicach, drzew oliwnych, która towarzyszy berlińskiemu Muzeum Żydowskiemu projektu D. Libeskinda- pat np. J.K. Lenartowicz (2003)

"To trW. . Aleja Nieobecnych" ustawiona tam w 2017 roku - ibidem w Madrycie, drzewa w donicach przed Muzeum Narodowym w Krako${ }^{37}$ Jak to ma miejsce na Muranowie w Warszawie

Jakw22@w Barceloni

LITERATURA

(1) 22@Barcelona, 10 Anys de renovació urbana, Ajuntament de Barcelona, Barcelona 2012
[2] Bialkiewicz J.J., Muzeum Katyńskie na terenie Cytadeli Warszawskie] - obiekt historyczny w interpretacji nowoczesnej architektury muzeal
hej, Wiadomosci Konserwatorskie - Journal of Heritage Conservation

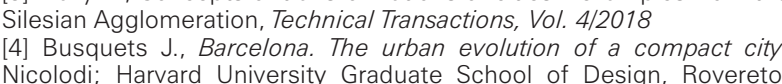

Cambridge, MA 2005
[5] Cymer A.. Morze z betonu, Architektura \& Biznes nr 06/2013
[6] Gyurkovich M., 22@Barcelona - The City of Knowledge Civilization. Technical Iransactions, Seria A, z. 4A/2012 (rok 109)
The

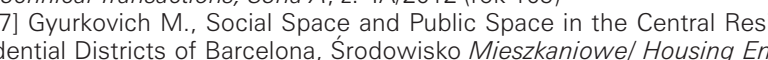
vironment, no. 10/2012 [8] Gyurkovich M. Hybrrdowe przestrzenie kultury we wspótczesnym
miescie europejkim, Wyd. PK. Kraków 2013 Skira, Milano 201

10] Kosiński W. Zieliński M., Urbanistyka krajobrazu i krajobraz urbani (111] Lenartowicz J.K.. Architektura trwogi, Polska Sztuka Ludowa -KonInstrtut Sztuki PAN, Fundacia Kuttur, 2003 12] Miralles R., Sierra P., Barcelona, Arqu

.

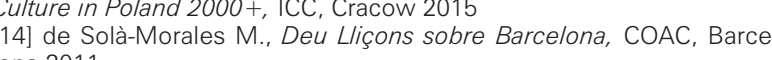

[15] Sudjic D., Jezyk miast, Karakter, Kraków 2017
[16] TIrata G., Piaty yelment A Architeturara \& Biznes nr. $02 / 2010$ 政 [18] Wejchert K., Elementy kompozycji urbanistycznej, Arkady, Warsza-

19] Wrażliwość dwóch pokoleń - o Muzeum Katýńskim Krzysztof My 201 Zachar.architektura.muratorp/us.pl- dostęp lipiec 2018

szczególinym uwzględnieniem roli parków publicznych, Wyd. PK, Kra [21] Zachariasz A., Nowoczesna architektura krajobrazu - wspótczesne
parki i place, Czasopismo Techniczne, Seria Architektura, z. 4A/2007 (rok

abroad, discuss this massacre. However, for the purposes of this
work, raw encyclopaedic facts are sufficient- www.encyklopedia. pwn.pl-retrieved in May 2018 ${ }_{28}^{28}$ And inaugurated as the Fortress of Alexander in 1834 -ibidem.
${ }_{22}$ From1963 a small museum functioned as a part of the Citade 2 From1963 a small museum functioned as a part of the Citadel
devoted to the members of the workers' movement repressed by the tsarist government, which was later converted into a Polish Army Museum, of which the museum under discussion is a bra

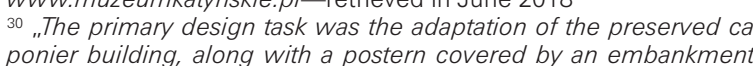
ponier building, along with a postern covered by an embankment
as well as its interior, including the so-called "watch path", the emas well as its interior, including the so-called "watch path", the em-
bankments a tragment of Carnot's wall, Nowomiejska Gate and the
building of the flank battery no. 31 into a museum." - from: JJ. Biatk-

31 The authors of the Katyn Museum in Warsaw are members of
BBGK Architekci: J. Belina Brzozowski, K. Grabowiecki, in cooper ation with a broad range of specialists: J. Kalina and K. Lang an the Capital City of Warsaw for the best public building in 2015; was also nom ated tor the European Union Prize for Contemporary

33 Landscape urbanism as a distinctive specialisation was discusse
in detail by W.Kosiński and M. Zielíski (2016) in detail by W. Kosiński and M. Zieliński (2016)
34 It brings to mind an installation composed of olive trees planted in cuboid concrete planters, which accompanies the Jewish Museeum
in Berlin by D. Libeskind--see, for instance I. L. Lenartowicz (2003)

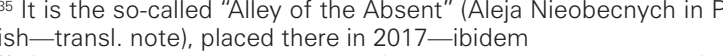
36 Green walls at the Musee du Quai Branly in Paris or the Caix
Forum in Madrid, trees in planters in front of the National Museum in Krakow.

37 As it has taken place in Muranów, Warsaw.
38 Like in $22 @$ in Barcelona

LITERATURA

[1]22@Barcelona, 10 Anys de renovació urbana, Ajuntament de Bar-
celona Barcelona 2012 [2] Bialkieviczz J.J., Muzeum Katýńskie na terenie Cytadeli Warszaw
skiej - obiekt historyczny w interpretacii nowoczesnei architektwy muzealnej, Wiadomosci Konserwatorskie - Journal of Heritage ConServation, hr $52 / 2017$
[3] Blazy R., Concepts of transformations of cities - examples from the Silesian Agglomeration, Technical Transactions, Vol. 4/2018 [4] Busquets J., Barcelona. The urban evolution of a compact city, Cambridge, MA 2005 [5] Cymer A. Morze z betonu, Architektura \& Biznes nr $06 / 2013$
[6] Gyurkovich M., $22 @ B$ Barcelona - The City of Knowledge Civiliza (6] Gyurkovich M., $22 @ B$ Barcelona - The City of Knowledge Civiliza
tion, Technical Transactions, Seria A, z. 4A/2012 (rok 109) tin, Gechrovivach M. , social Space and Public Space in the Central Resi-
dential Districts of Barcelona, Srodowisko Mieszkaniowe/ Housing dential Districts of Barcelona, Środowisko Mieszkaniowe/ Housing
Environment, no. 10/2012 [8] Gyurkovich M., Hybrydowe przestrzenie kultury we wspótczes. nym mieście europejskim, Wyd. PK., Kraków 2013
[9] Ingrosso C., Barcelona. Architecture, City and Society 1975-2015,
Skir Milano 2011 . Skira, Milano 011 . [10] Kosińnki W. Zieliński M. Urbanistyka krajobrazui krajobraz urba
nistyczny. Teoria. Praktyka. Edukacja, Przestrzeńi i Forma nr $25 / 2016$ nistyczny. Teoria. Praktyka. Edukacja, Przestrzeń i Forma nr $25 / 2016$
[11] Lenartowicz J.K., Architektura trwogi, Polska Sztuka Ludowa-

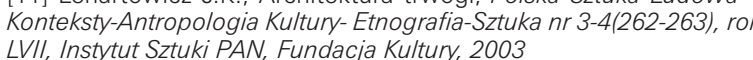
LVII, Instytut Sttuki PAN, Fundacia Kulturn, 2003
[12] Miralles R., Sierra P., Barcelona, Arquito 1979-2010. Editions Poligrata. Barcelona 2010 201 recta contemporàn [13] Purchla J., Sepiof J. (eds.), Form Follows Freedom, Architecture
for Culture in. Poland $2000+$ CC C Cracow 2015 for Cuiture in Poland 2000+, ICC, Cracow 2015
[14] de Solà-Morales M., Deu Liģons sobre Barcelona, COAC, Bar-

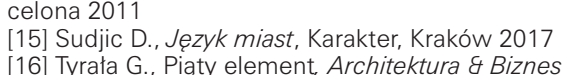
. 02/2010 search based on examples from Krakow, Technical Transactions, Vol. [18] Wejchert K., Elementy kompozycji urbanistycznej, Arkady, War19] Wrażiwość́ dwóch pokoleń - O Muzeum Katýnskim Krizszof Mycielski, www. architektura.muratoroplus.plol - dostepl lipiec 2018 [20] Zachariasz A., Zieleń jako wspotczesny czynnik miastotwórczy
ze szczególnym uwzględnieniem roli parków publicznych, Wyd. PK. Kraków, 2006
[211Zachariasz A. Nowoczesna architektura krajobrazu - wspótczesn parki i place, Czasopismo Techniczne, Seria Architektura, z. 4 A A/2007
(rok 104)

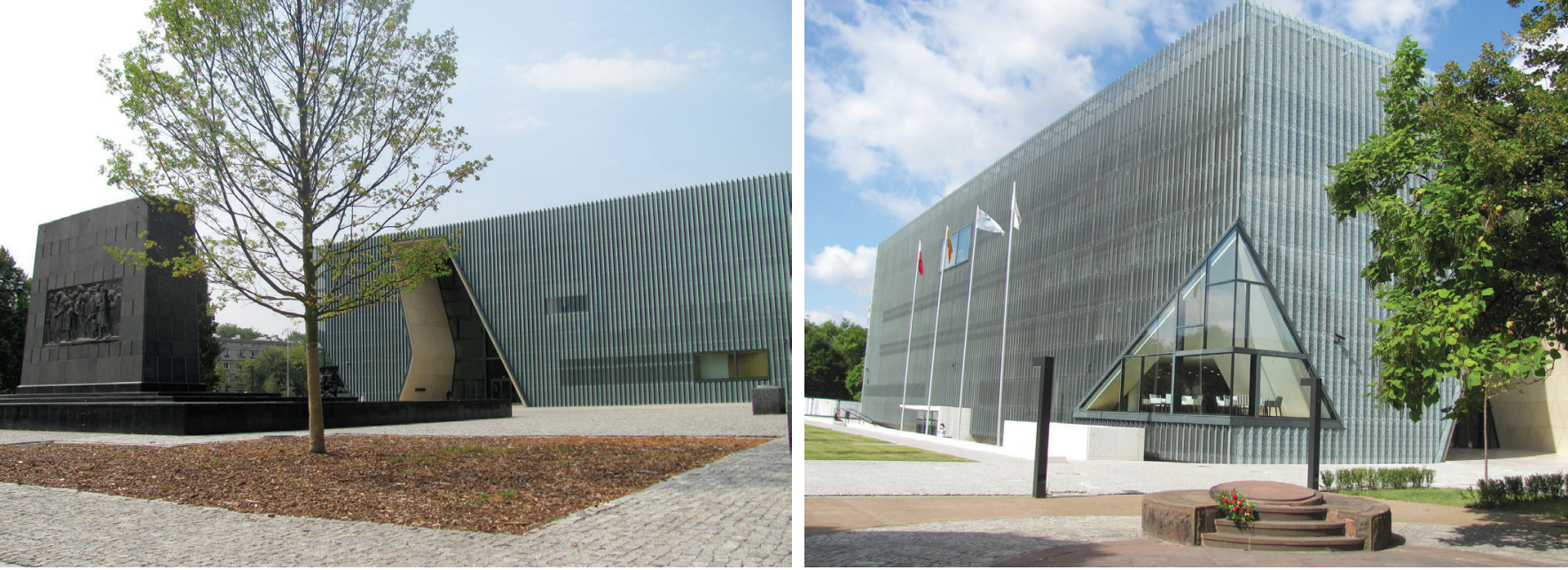

II. 1. II Pomnik Bohaterów Getta i Muzeum Żydowskie na Skwerze Willy'ego Brandta w Warszawie - fot. M. Gyurkovich / II Monument of the

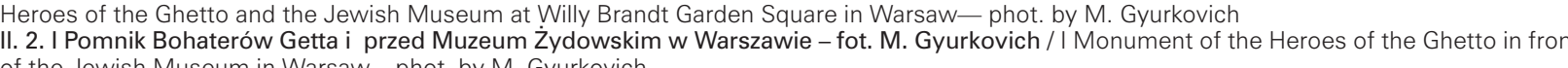

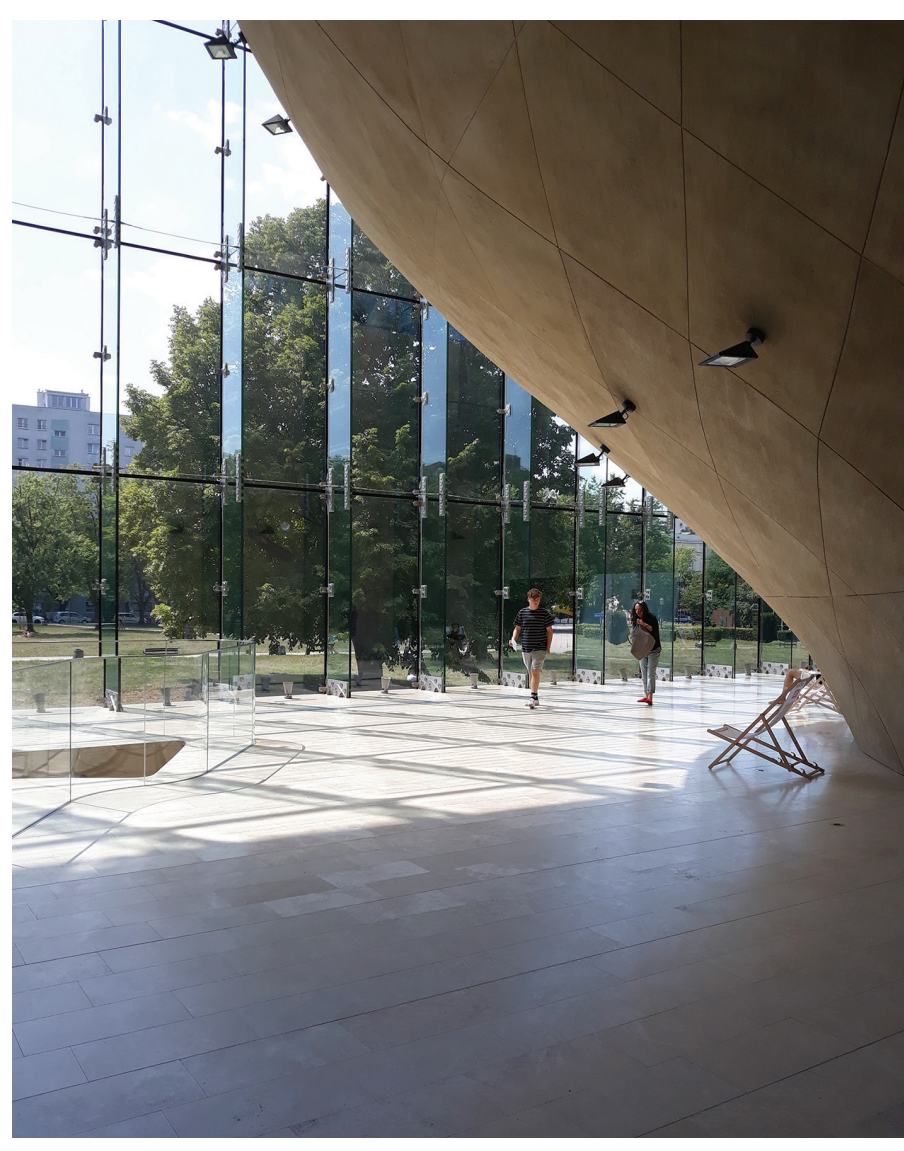

I1. 3. Skwer Will'ego Brandta widziany $z$ muzealnego foyer -
fot. M. Gyurkovich / Willy Brandt Garden Square seen from the

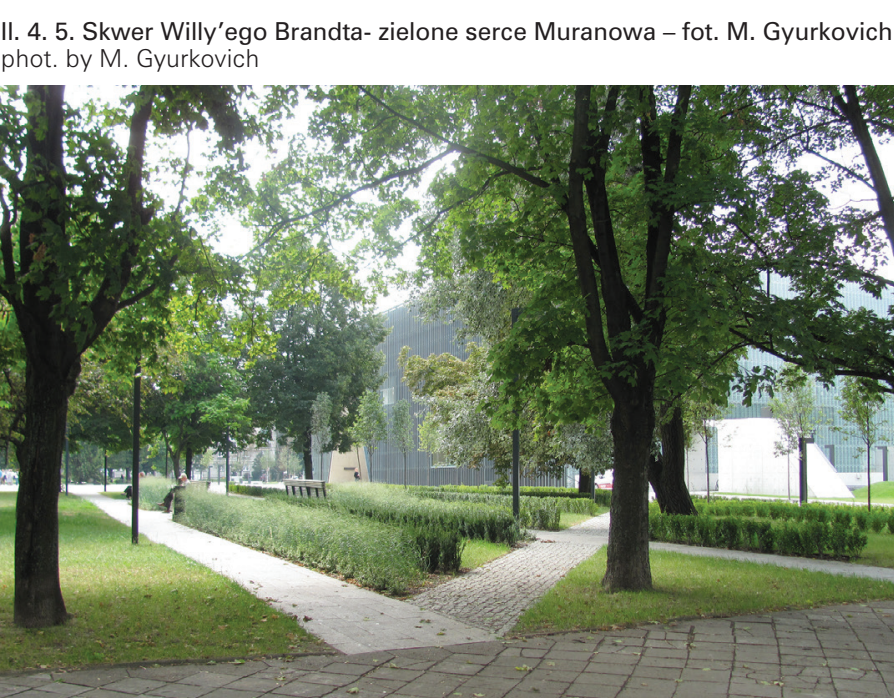

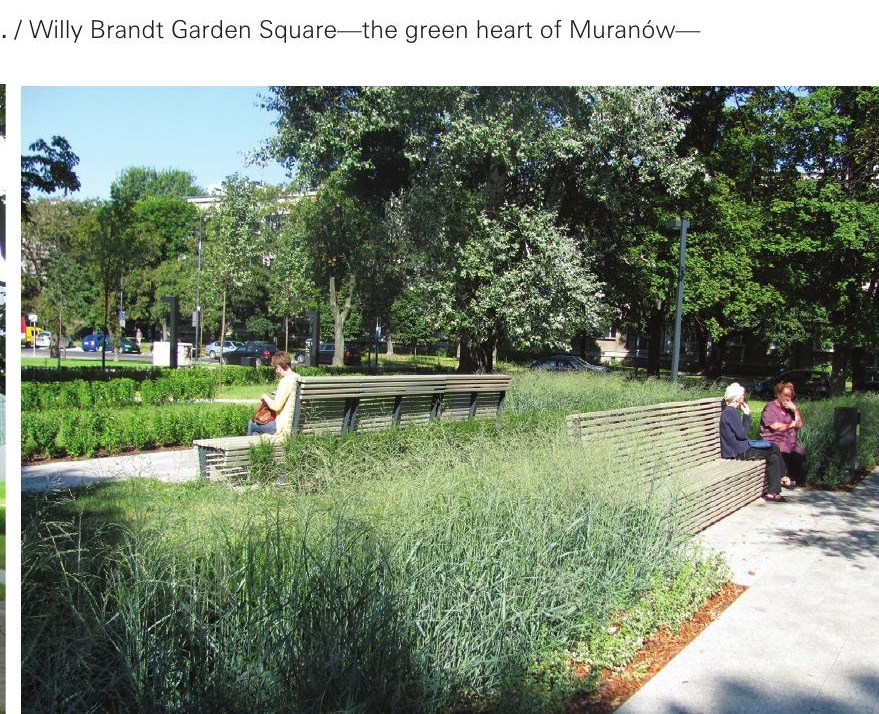




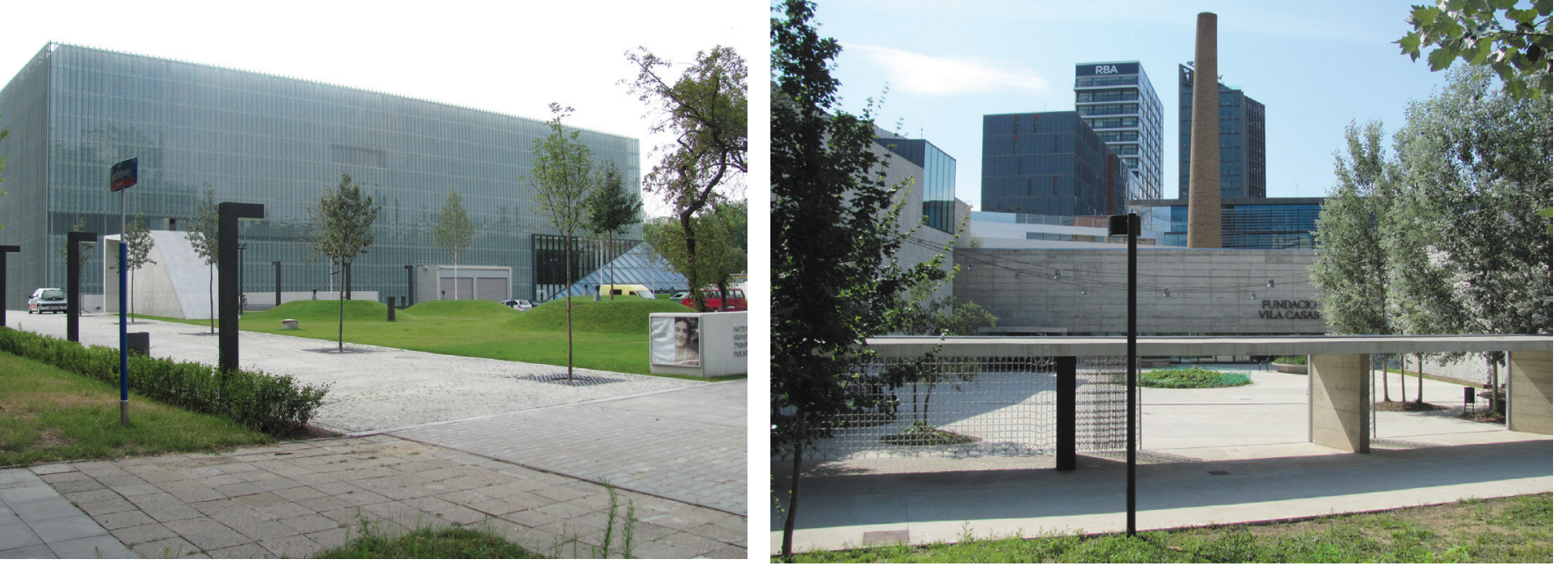

11. 6. Zagospodarowanie terenu wokół parkingów i dojazdów do Muzeum Żydowskiego w Warszawie - fot. M. Gyurkovich / The site development around the parking spaces and driveways to the Jewish Museum in Warsaw- phot. by M. Gyurkovich
II. 7. Muteum Can Framis w Barcelonie, otoczone zielenia - fot. M. Gyurkovich / The Can Framis museum in Barcelona, surrounded by greenery-
phot by M. Gyurkvich
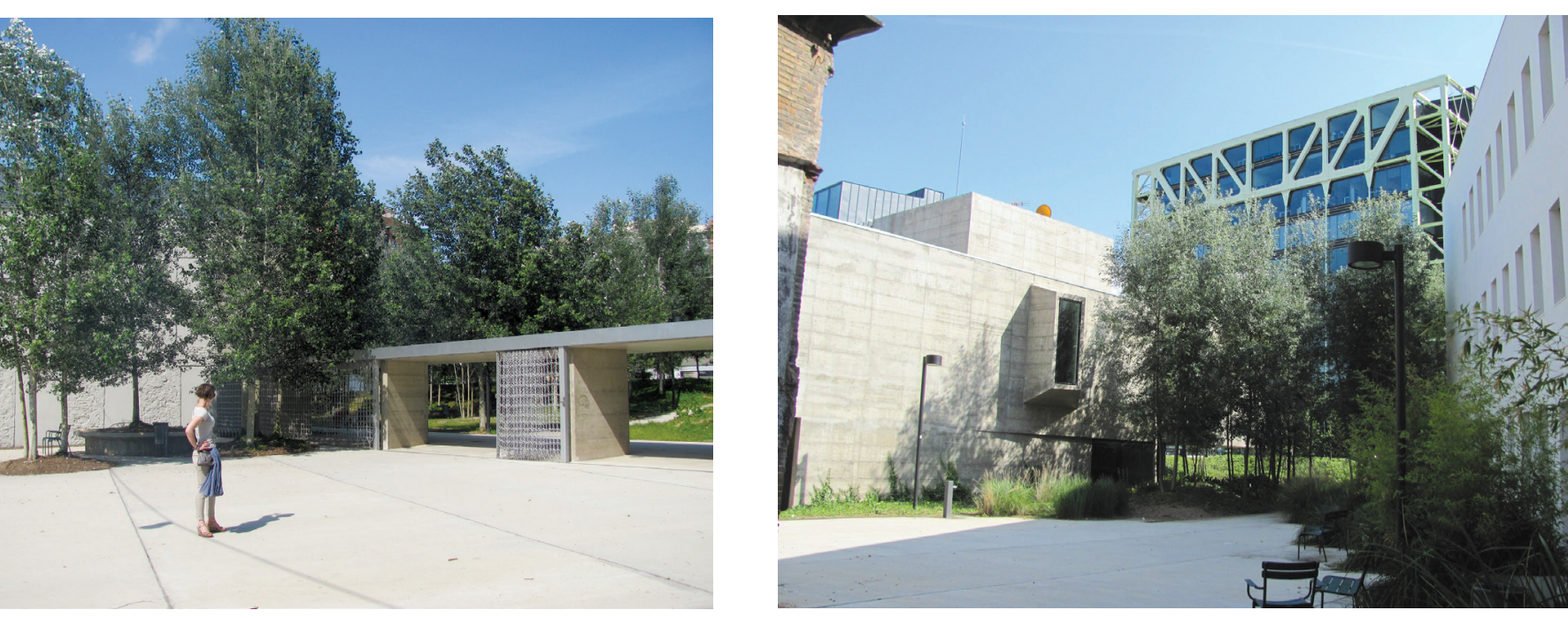

II. 8. Can Framis- gtówny wejściowy dziedziniec- widok
the direction of the gardens- phot by M. Gyurkovic

the dir. Obiekty niewielkiego kompleksu Can Framis i towarzyszaca im zieleń kadruja widoki na otaczająca tkanke urbanistyczna 22@ - fot. M. Gyur-
kovich / The buildings of the small Can Framis complex and their accompang $\mathrm{kovich} /$ The buildings
by M. Gyurkovich

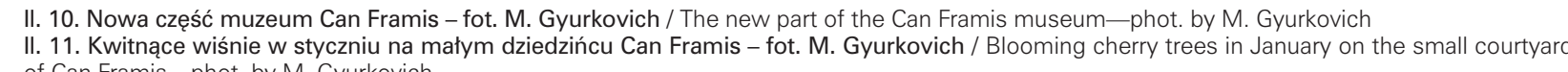
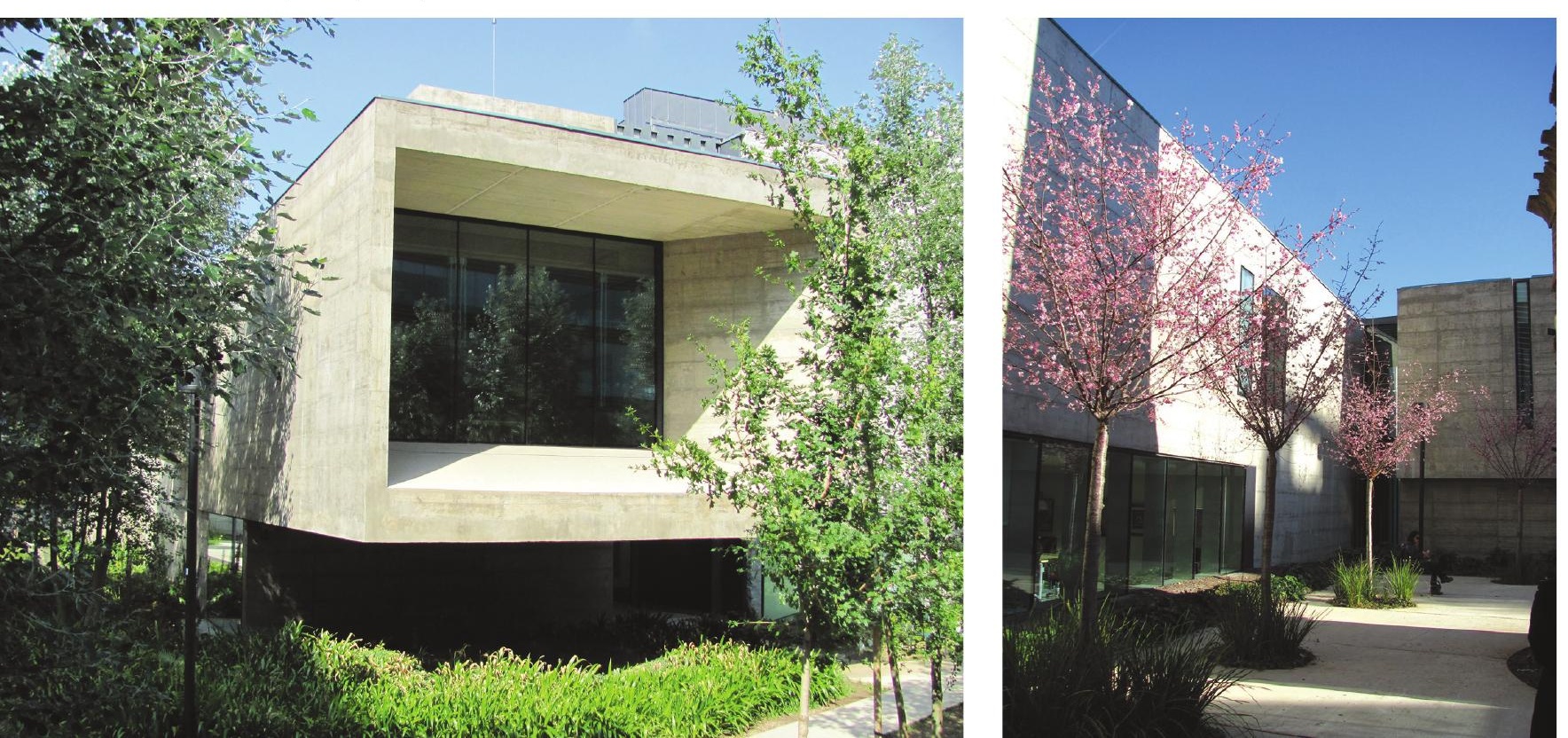

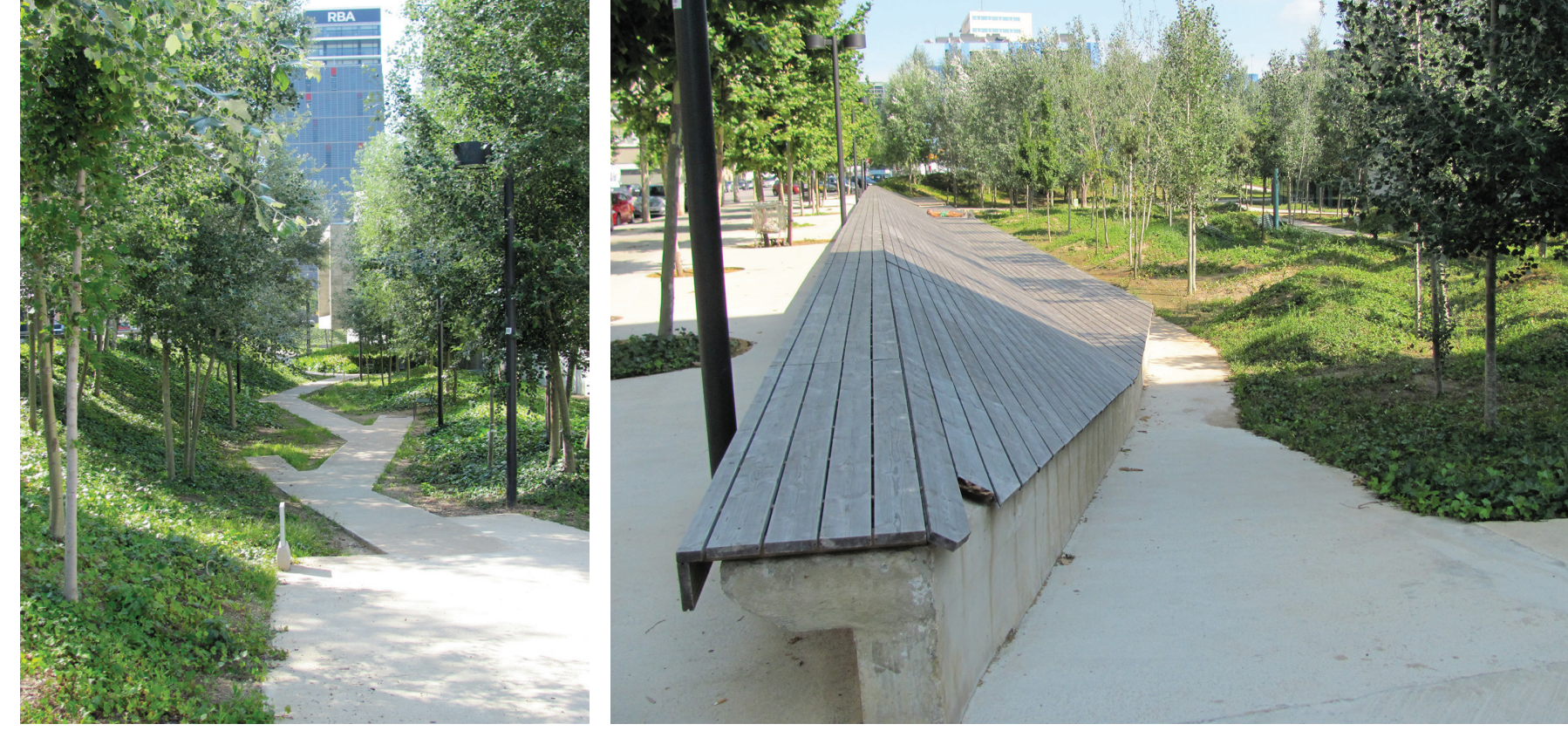

II. 12. Gesta zielen ogrodów Miquel Marti Pol stanowi oaze chtodu w czasie letrich miesiecy - fot. M. Gyurkovich / The thick greenery of the

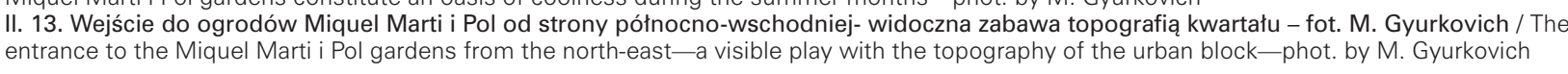
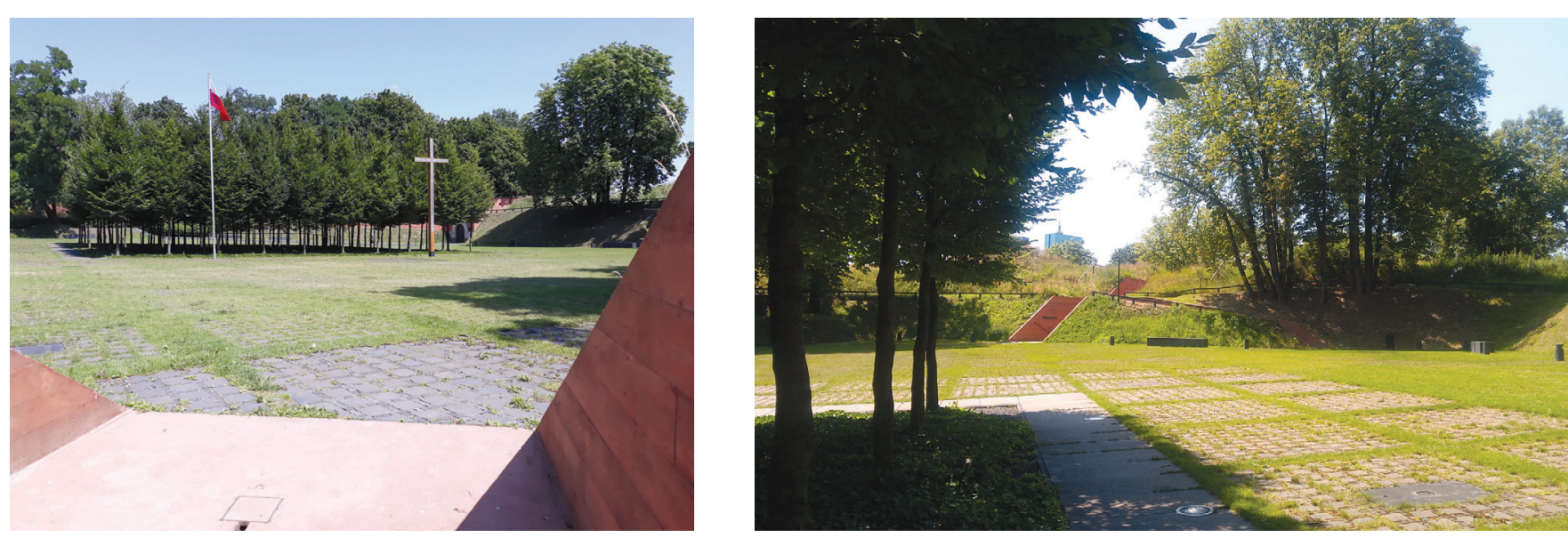

11. 14. Murzeum Katyrskcie w Cytadeli Warszawskiej - Instalacia WARTA - lipiec 2018 - fot. M. Gyurkovich / The Katyn Museum at the Warsaw II. 15. Warszawa- Muzeum Katýnskie - widok spod WARTY na plac apelowy - fot M. Gyurkovich / Warsaw-Katyn Museum-view from the site

11. 16. Muzzeum Katyriskie - wyjscie z wewnetrznej ekspozycij do dawnej fosy fortecznej - fot. M. Gyurkovich / The Katyn Museum—-ext from the

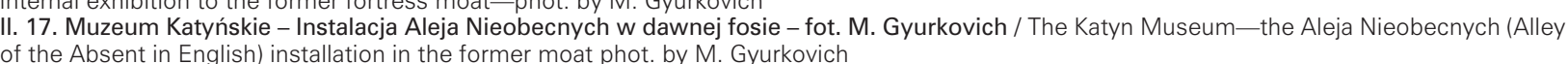

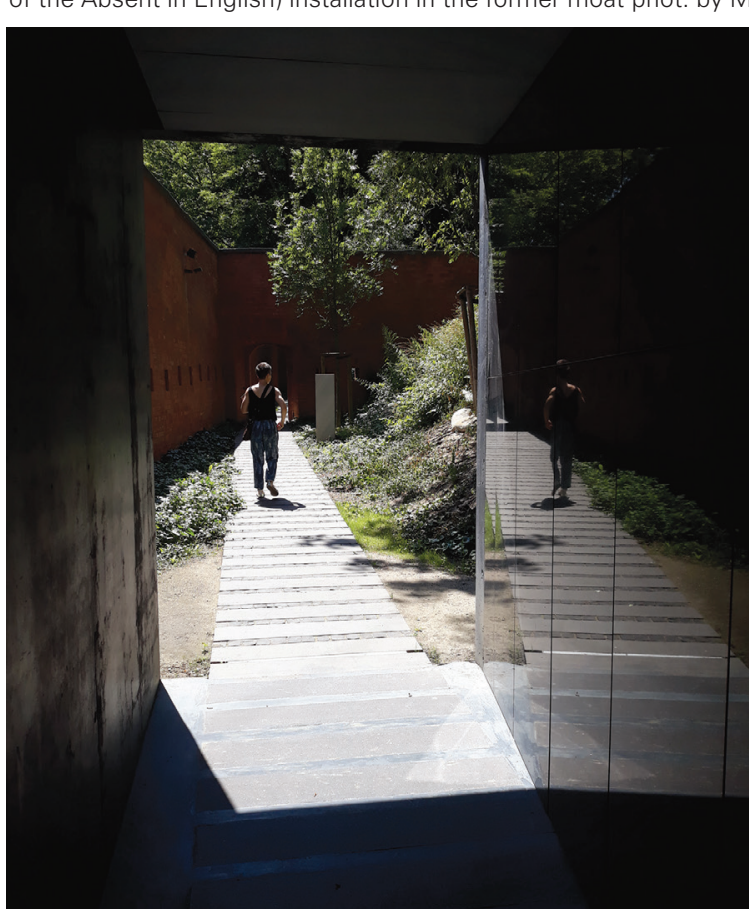

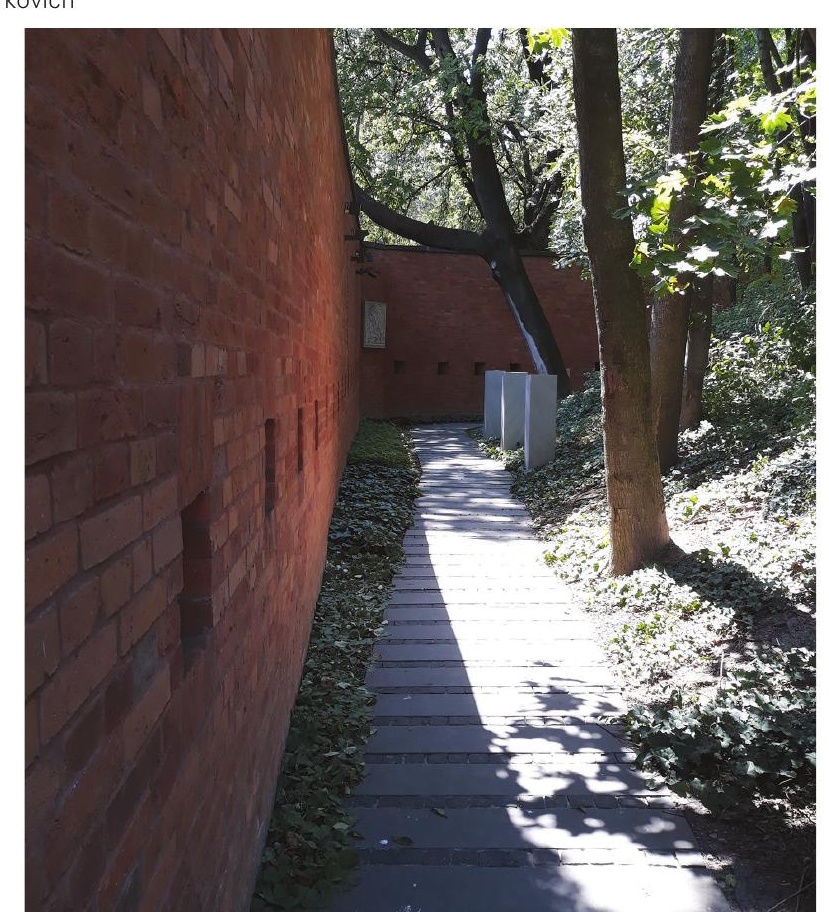




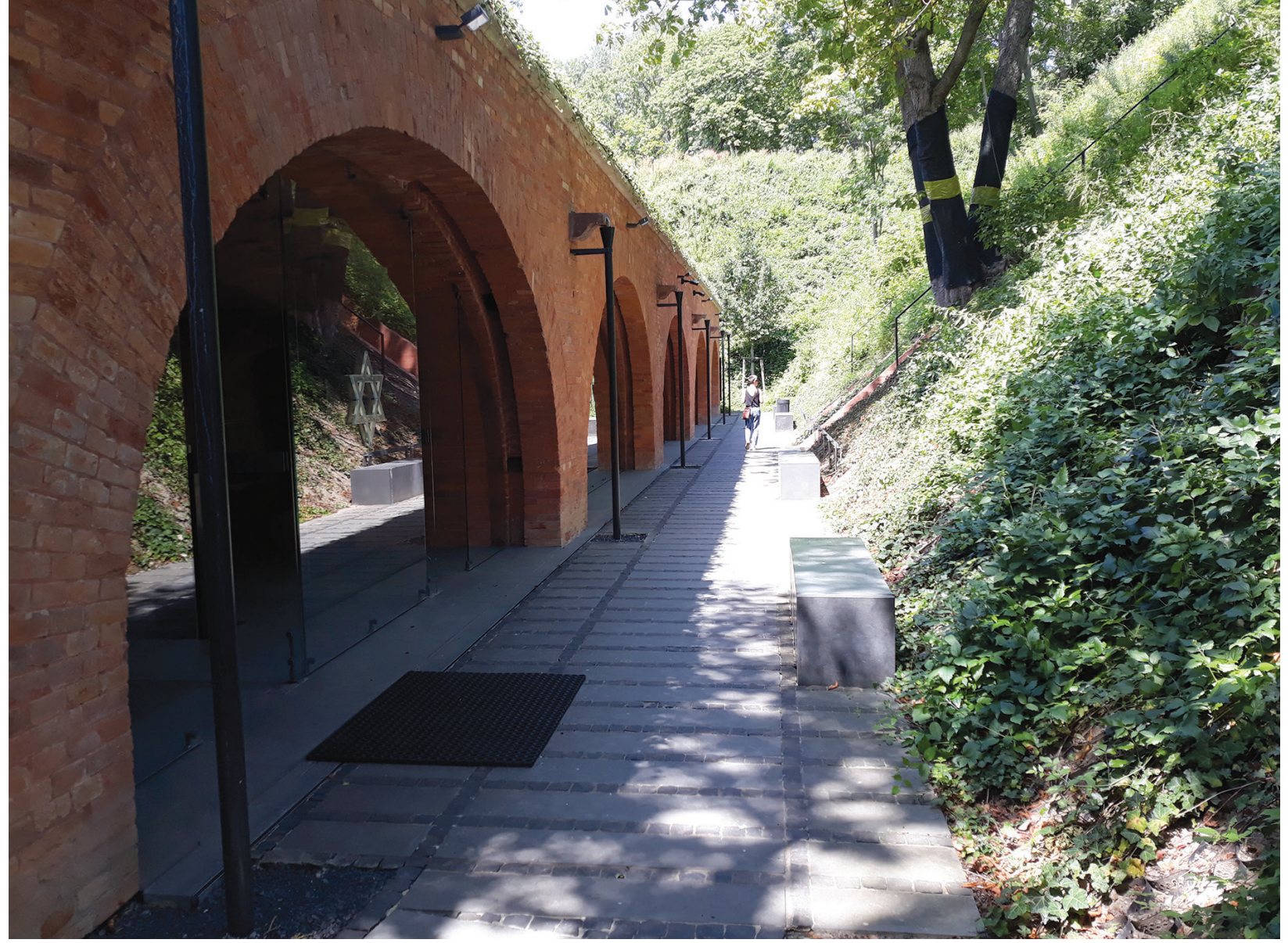

II. 18. Muzeum Katyńskie - Strefa Pamięci w arkadach dawnej baterii bazowej - fot. M. Gyurkovich / The Katyn Museum—the Memorial Space in the arcades of the former flanking battery-phot. by M. Gyurkovich

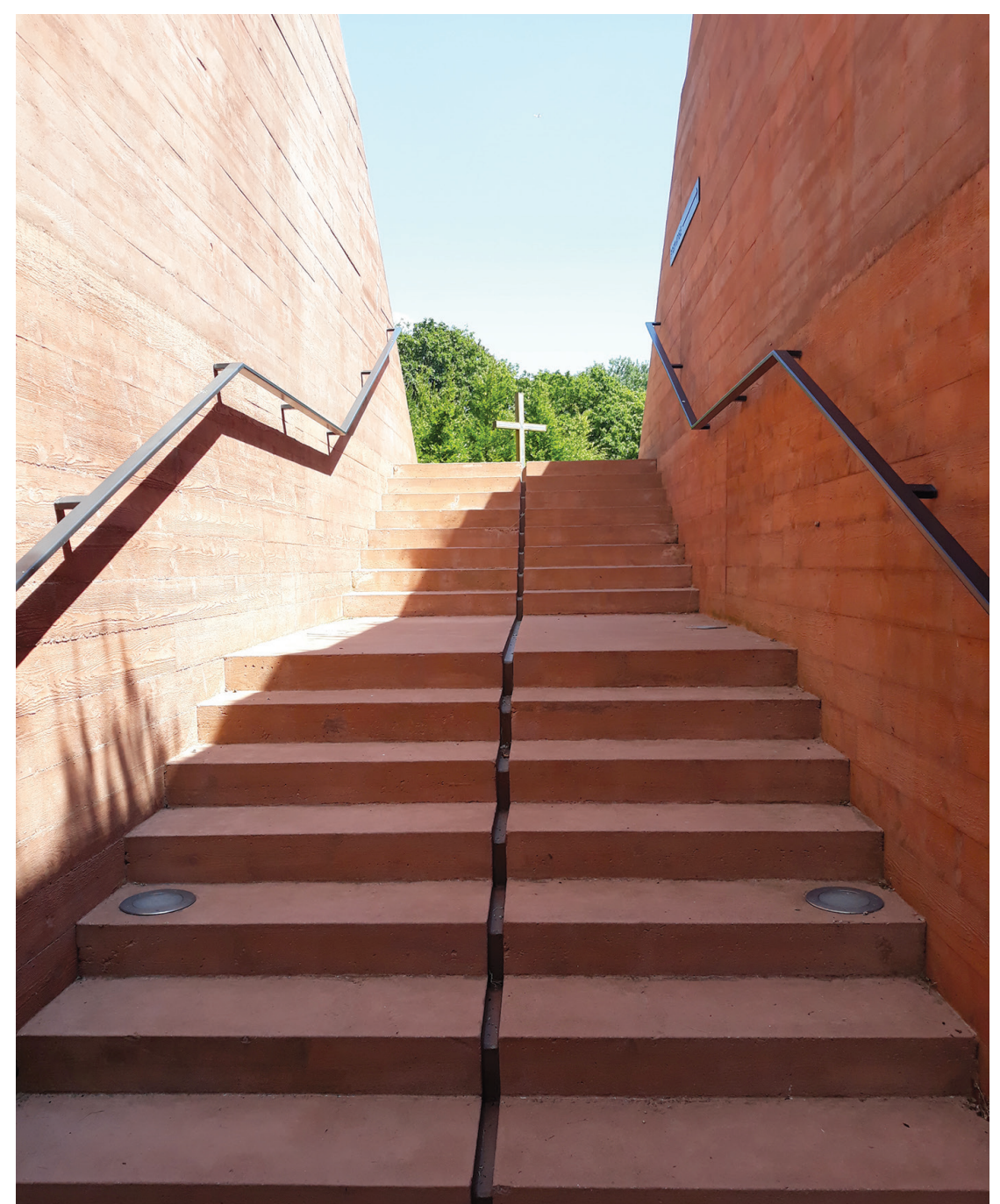

II. 19. Muzeum Katyńskie- schody prowadzące ze Strefy Pamięci w kierunku Placu Apelowego - fot. M. Gyurkovich / The Katyn Museum-stairs leading from the Memorial Space in the direction of the drill square-phot. by M. Gyurkovich 